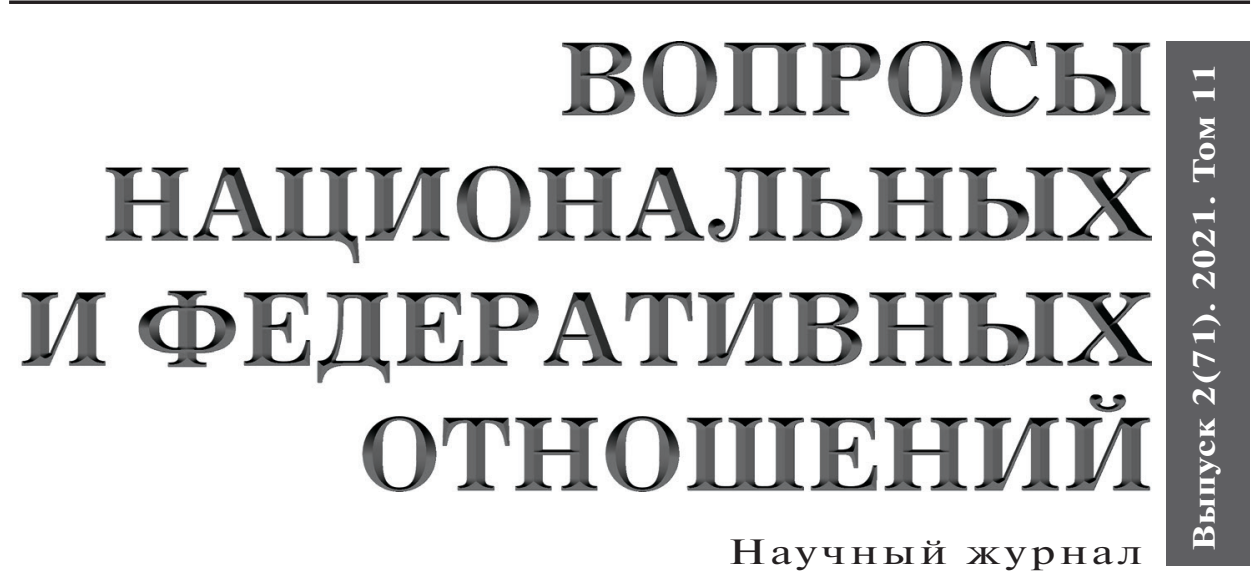

Журнал «Вопросы национальных и федеративных отношений» включен в перечень рецензируемых научных изданий ВАК, в которых должны быть опубликованы основные научные результаты на соискание ученой степени кандидата наук, на соискание ученой степени доктора наук по политическим и историческим наукам 


\section{Научный журнал}

Вячеслав Александрович МИХАЙЛОВ

Рамазан Гаджимурадович АБДУЛАТИПОВ

\section{Любовь Федоровна БОЛТЕНКОВА \\ Владимир Иванович ВАСИЛЕНКО}

Владимир Александрович ВОЛОх

Вадим Витальевич

ГАЙДУК

Леокадия Михайловна ДРОБИЖЕВА

\section{Владимир Юрьевич} ЗОРИН

Раушан Мусахановна КАНАПЬЯНОВА

\section{В. Микаэль} КАССАЕ НЫГУСИЕ

Геннадий Яковлевич КОЗЛОВ

Игорь Георгиевич КОСИКОВ

Николай Павлович МЕДВЕДЕВ

Марина Николаевна МОСЕЙКИНА

Александр Данилович НАЗАРОВ

Дарья Вячеславовна ПЕРКОВА

Александр Васильевич ПОНЕДЕЛКОВ

Дмитрий Егорович СЛИЗОВСКИЙ

Шукран Саидовна СУЛЕЙМАНОВА

Жибек Сапарбековна СЫЗДЫкОВА
Председатель Совета, д.и.н., профессор, зав. кафедрой национальных и федеративных отношений РАНХ и ГС при Президенте РФ

\section{Редакционный Совет}

д.ф.н., постоянный представитель Российской Федерации при Организации Исламского сотрудничества

д.ю.н., профессор РАНХ и ГС при Президенте РФ

д.п.н., профессор Российской академии народного хозяйства и государственной службы при Президенте РФ

д.П.н., профессор Государственного университета управления

д.п.н., профессор Башкирского государственного университета

д.и.н., руководитель Центра исследования межнациональных отношений Института Социологии ФНИСЦ РАН

д.п.н., руководитель Центра по научному взаимодействию с общественными организациями, СМИ и органами государственной власти ИЭА РАН

д.п.н., профессор кафедры международного культурного сотрудничества МГИК

д.и.н., профессор кафедры теории и истории международных отношений Российского университета дружбы народов

д.и.н., профессор Рязанского государственного университета им. С.А. Есенина

д.и.н., главный научный сотрудник Института этнологии и антропологии РАН

д.п.н., профессор Российского университета дружбы народов

д.и.н. профессор, заведующая кафедрой истории России Российского университета дружбы народов

д.и.н., профессор, зам. руководителя кафедры по научной работе Московского авиационного института к.п.н., ответственный редактор

д.п.н., профессор, заведующий кафедрой политологии и этнополитики Южно-Российского института управления - филиал РАНХ и ГС при Президенте РФ

д.и.н., профессор кафедры истории России Российского университета дружбы народов

д.п.н., профессор Российской академии народного хозяйства и государственной службы при Президенте РФ

д.и.н., профессор, заведующая кафедрой стран Центральной Азии и Кавказа Института стран Азии и Африки Московского государственного университета имени М. В. Ломоносова, заместитель главного редактора журнала

Редакционная коллегия

Главный редактор - СУЛЕЙМАНОВА Ш.С., д.п.н., профессор РАНХиГС

Члены ред. коллегии:

Волох В.А. (зам. главного редактора),

Сыздыкова Ж.С. (зам. главного редактора),

Перкова Д.В. (ответственный редактор)

Болтенкова Л.Ф., Дробижева Л.А. Слизовский Д.Е.

\author{
УЧРЕЖДЕН \\ ООО «Издательство \\ «Наука сегодня»
}

\section{ЖУРНАЛ ВКЛЮЧЕН \\ В ПЕРЕЧЕНЬ ВАК РФ}

Журнал зарегистрирован Федеральной службой по надзору в сфере массовых коммуникаций,

связи и охраны культурного наследия

Регистрационный номер

ПИ № ФС77-47487

от 25 ноября 2011 г.

Журнал издается ежемесячно

Журнал включен в базу РИНЦ

(Российский индекс научного цитирования)

Включен в каталог

Ulrich's Periodicals Directory

Пятилетний импакт-фактор журнала: 1,006

Адрес редакции:

115598 , г. Москва, ул. Загорьевская, д. 10, корп. 4, цокольный этаж, помещение I, комната 7-1, офис 4

Тел.: (910) 463-53-42

www.etnopolitolog.ru

E-mail: etnopolitolog@yandex.ru

Мнение авторов может не совпадать с мнением редакции.

При перепечатке ссылка на журнал обязательна.

Научные статьи, публикуемые в журнале подлежат обязательному рецензированию.

Ответственный редактор Перкова Д.В.

Компьютерная верстка Анциферова А.С.

Подписано в печать 25.02.2021.

Формат 60×84/8. Объем 24,3. Печать офсетная. Тираж - 1000 экз. (1-й завод - 500 экз.) Заказ № 000

Отпечатано в типографии ООО «Белый ветер»

115054, г. Москва, ул. Щипок, 28

Тел.: (495) 651-84-56 
ISSN 2226-8596 (print)

12 выпусков в год и

2 выпуска в год переводной (англ.) версии

Языки: русский, английский

http://etnopolitolog

Входит в перечень рецензируемых научных изданий ВАК РФ

Включен в каталог периодических изданий Ульрих (Ulrich’s Periodicals Directory: http://www.ulrichsweb.com) Материалы журнала размещаются на платформе РИНЦ Российской научной электронной библиотеки, Electronic Journals

Library Cyberleninka

Подписной индекс издания в каталоге агентства Роспечать 70114

\section{Цели и тематика}

Журнал ВОПРОСЫ НАЦИОНАЛЬНЫХ И ФЕДЕРАТИВНЫХ ОТНОШЕНИЙ - периодическое международное рецензируемое на ᄀучное издание в области политических исследований. Журнал является международным как по составу редакционного совета и редколлегии, так и по авторам и тематике публикаций.

Научный журнал издается с 2011 года в издательстве «Наука сегодня». С 2018 года издается переводная (англ.) версия журнала. С момента своего создания, журнал ориентировался на высокие научные и этические стандарта и сегодня является одним из ведущих политологических журналов России.

Цель журнала - способствовать научному обмену и сотрудничеству между российскими и зарубежными политологами

Журнал предназначен для публикации результатов фундаментальных и прикладных научных исследований. Тематическая направленность журнала отражается в следующих постоянных рубриках: «Отечественная история, этнология и этнография», «История международных отношений и мировой политики», «История и философия политики», «Политические институты, процессы и технологии», «Политическая культура, этнополитика и идеологии», «Политические проблемы международных отношений и глобализации».

Формат публикаций: научные статьи, обзорные научные материалы, материалы круглых столов, научные рецензии, научные сообщения, посвященные исследовательским проблемам в сфере политики и политологии.

В своей деятельности редакционный совет и редколлегия журнала руководствуется принципами, определяемыми ВАК России для научных журналов, в том числе: наличие института рецензирования для экспертной оценки качества научных статей; информационная открытость издания; наличие и соблюдение правил и этических стандартов представления рукописей авторами.

Целевой аудиторией журнала являются российские и зарубежные специалисты-политологи, а также аспиранты и магистры, обучающиеся по направлениям политология, государственное и муниципальное управление и международные отношения.

Журнал строго придерживается международных стандартов публикационной этики, обозначенных в документе СОРЕ (Committee on Publication Ethics) http://publicationethics.org

Полные сведения о журнале и его редакционной политике, требования о подготовке и публикации статей, архив (выпуски с 2011 года) и дополнительная информация размещена на сайте: http://etnopolitolog.ru

Электронный адрес: etnopolitolog@yandex.ru

ISSN 2226-8596 (print)

12 issues a year plus 2 issues a year of the translated (eng.) version Languages: Russian and English http://etnopolitolog

Included in the list of peer-reviewed scientific publications of the Higher Attestation Commission of the Russian Federation Included in the Ulrich's Periodicals Directory Materials of the journal are placed on the RSCI platform of the Russian scientific electronic library - Electronic Journals Library Cyberleninka Subscription index of the journal in the Rospechat Agency catalogue is: 70114

\section{Objectives and themes}

Academic journal "Issues of National and Federative Relations" is an international peer-reviewed scientific periodical in the field of political studies. The journal has an international character because of the composition of its Editorial Board, its editors, its contributing authors and topics of its publications.

The scientific journal is published since 2011 at the "Publishing House "Science Today". Translated (eng.) version of the journal is published since 2018. Since its inception, the journal was guided by high scientific and ethical standards and today it is one of the leading political science journals in Russia.

The purpose of the journal is to promote scientific exchange and cooperation between Russian and foreign political scientists.

The journal is intended for the publication of the results of fundamental and applied scientific research. Thematic focus of the journal is reflected in the following permanent headings: "Domestic history, ethnology and ethnography", "History of international relations and world politics", "History and philosophy of politics", "Political institutions, processes and technologies", "Political culture, ethnopolitics and ideologies", "Political problems of international relations and globalization."

Format of publications: scientific articles, reviews, scientific materials, materials of round tables, scientific reviews, scientific reports devoted to research problems in the field of politics and political science.

The Editorial Board and the editors of the journal in their activities are guided by the principles defined by VAK of Russia for scientific journals, including: presence of the institute of peer review for the expert quality assessment of scientific articles; information openness of the publications; availability and compliance with the rules and ethical standards for the submission of manuscripts by the authors.

The target audience of the journal is Russian and foreign specialists-political scientists, as well as graduate students and masters in the fields of political science, state and municipal management and international relations.

The journal strictly adheres to the international publishing standards and publication ethics identified in the COPE (COmmittee on Publication Ethics) document. http://publicationethics.org.

Full details of the journal and its editorial policy, requirements to the preparation and publication of articles, archive (issues since 2011) and additional information are available on the website: http://etnopolitolog.ru

E-mail address: etnopolitolog@yandex.ru 
ОТЕЧЕСТВЕННАЯ ИСТОРИЯ, ЭТНОЛОГИЯ И ЭТНОГРАФИЯ

Костриков С.П. Оценка событий 1903 г. в Македонии

и Старой Сербии приверженцами идеи славянского единства

в русском общественном мнении (На примере анализа

материалов «Известий С.-Петербургского Славянского

Благотворительного Общества»)

Бориснёв С.В., Вититнев С.Ф. Спецпропаганда

как составная часть партийно-политической работы

в советских Вооруженных Силах

Плеханов А.А. «Господа юнкера, с кем вы были вчера?»

(восстание юнкеров в Петрограде 29 октября 1917 г.

глазами участников и очевидцев)

Истягина-Елисеева E.A. Спортивно-историческое наследие:

проблемы исторических исследований

Макина А.И. Социальная защита детей

в традиционном хакасском обществе

Aнтонова E.Г. Подготовка учительских кадров

в Симбирской губернии в конце XIX - начале XX века

Дегтярева Н.А. ХХ съезд КПСС (к историографии вопроса)................ 364

Kроm H.C. Роль репродуктивных установок

в формировании репродуктивного поведения

(по материалам этносоциологического исследования)

Петрухин А.М. Реакция британской прессы на роспуск

Государственной Думы Российской империи I созыва

ТЕОРИЯ, ФИЛОСОФИЯ И ИСТОРИЯ ПОЛИТИКИ

Власов В.И. Статус Бога в Русской (Российской)

правовой системе (постановка вопроса)

Болтенкова Л.Ф. Библия как источник права (часть пятая)................... 400

Цанава Б.3. Философское наследие Т. Гоббса

и современные либеральные теории

общественного договора

ПОЛИТИЧЕСКИЕ ИНСТИТУТЫ, ПРОЦЕССЫ И ТЕХНОЛОГИИ

Равочкин Н.H. Властные практики

в странах мировой периферии ...

Зубов В.В., Родионова М.Е., Емелин А.А.

Отношение населения к вакцинации от коронавируса:

сравнительный анализ исследований.

Tюков Н.A., Никулин E.P. Российский педагог

в социальных сетях: дискурсивная повестка,

ифровая активность и механизмы коммуникации ......

298 ВОПРОСЫ НАЦИОНАЛЬНЫХ И ФЕДЕРАТИВНЫХ ОТНОШЕНИЙ • ВЫПУСК 2(71) • 2021 • Том 11 
Кочетков $\boldsymbol{E . E . ~ О с о б е н н о с т и ~ ф е д е р а л и з м а ~}$ в арабских странах (на примере Ирака).

Рабат Луджан. Сложности разрешения

сирийского конфликта: внешнее вмешательство

и «либеральный» подход к миростроительству .....

Воскресенский Ф.A. Проблемы судебного федерализма

в политической системе современной России

Денисенко П.В. Big Data в системе отношений

«государство-общество»: потенциал и некоторые

сферы применения (на примере США)

Пилягин К.А. Политические механизмы

(аспекты категориального анализа) 508

Семибоков Д.А. Современная структура

научных представлений о непризнанных республиках

как особых политических институтах

Иванов П.В., Плотников Д.И. Стабилизация

политической системы через государственную политику

национального примирения

ПОЛИТИЧЕСКАЯ КУЛЬТУРА И ИДЕОЛОГИИ

Львов С.В., Максимова А.А., Нечаева С.В. Механизмы

и мотивация участия педагогического сообщества

в политических и гражданских процессах

ТЕОРИЯ И ИСТОРИЯ МЕЖДУНАРОДНЫХ ОТНОШЕНИЙ, ВНЕШНЕЙ И МИРОВОЙ ПОЛИТИКИ

Тушков A.A., Степанова C.C. Противоречия и дихотомии

конфликтного потенциала Восточного Средиземноморья.

Каренин Д.М., Кузьмин В.А. Япония и ЕЭС:

долгий путь к сотрудничеству .

Тушков А.А., Кравченко Ю.С. Россия на международном рынке образовательных услуг. Проблемы и поиски формирования модели интернационализации образования 566

Гехт А.Б., Молчанова Т.В., Цыгоняева А.Ю., Перевозчикова В.А.

Ближневосточный вектор внешней политики США

в период президентства Дональда Трампа

(на примере Ирана и Израиля).

Станкевич И.Г. Река Рейн в восприятии римлян

(І в. до н.э. - начало V в. н.э.). 588

Гехт А.Б., Неровный А.В., Потапенко Т.Г.

На пути к Единой Европе: институциональная архитектура

Европейского объединения угля и стали 594 
Шиматюк О.А. Энергетическое сотрудничество России и Евросоюза в условиях «Зеленой сделки» 603 Антонова Н.Г. Новый альянс «США-Израиль-арабские монархии Персидского залива» в регионе Ближнего Востока: причины сближения и последствия для региональной геополитики

Аржсанов И.А. Арктика в системе современных международных отношений:

лейтмотив соперничества в регионе

Шабловский В.С. Республика Сербская: современные политические реалии и перспективы

Гунду Тересе Мосес, Олувакайоде Олумиде Эммануэль.

Analyzing the Effect of Coronavirus

on Nigeria's Education System/Анализ влияния

коронавируса на систему образования в Нигерии 640

\section{РЕЦЕНЗИИ}

Слизовский Д.Е., Амиантов А. А. Есть ли у правительства ресурсы справиться с протестным движением?

(Рецензия на статью С.И. Морозова и К.М. Макаренко «Технологии регулирования деструктивных форм протестной деятельности в современной России»)

\section{КОНФЕРЕНЦИИ}

Сапрынская Д.В., Сапарбекова Д.С. Международная научно-практическая конференция «Российско-монгольские отношения: от истоков до современности». 661

НАШИ АВТОРЫ 680

ТРЕБОВАНИЯ К ОФОРМЛЕНИЮ РУКОПИСЕЙ 688 
УДК 327.83

А.А. ТУШКОВ

профессор кафедры международных отномений и права Владивостокского государственного университета экономики и сервиса, Россия, г. Владивосток

Ю.С. КРАВЧЕНКО

начальник отдела международной академической мобильности Владивостокского государственного университета экономики и сервиса, Россия, г. Владивосток

\title{
РОССИЯ НА МЕЖДУНАРОДНОМ РЫНКЕ ОБРАЗОВАТЕЛЬНЫХ УСЛУГ. ПРОБЛЕМЫ И ПОИСКИ ФОРМИРОВАНИЯ МОДЕЛИ ИНТЕРНАЦИОНАЛИЗАЦИИ ОБРАЗОВАНИЯ
}

\begin{abstract}
Данная статья посвящена актуальной теме - исследованию современных трансформачионных процессов российской высшей школьы. В частности, автор исследует феномен массовизации выстего образования и его влияния на систему образования. В статье анализируются такие явления как глобализаџия и интернаџионализаџия выстего образования. Рассматриваются вопросы экспорта образовательных услуг в контексте интерначионализачии университета как основного фактора повышения качества образования. Автор уделяет внимание роли регионального университета в формировании и реализаџии стратегии России по укреплению своего положения на международном образовательном рынке. Рассматриваемая тема будет интересна специалистам, занимающимся вопросами изучения и развития экспортного потенциила российской системы высшего образования.
\end{abstract}

Ключевые слова: экспорт образования, глобализация, интернационализачия, трансформачия образования. 
A.A. TUSHKOV

Professor of International Relations and Law, Vladivostok State University of Economics and Service,

Vladivostok, Russia

YU.S. KRAVCHENKO

Head of academic mobility office of Vladivostok

State University of Economics and Service,

Vladivostok, Russia

\section{RUSSIA ON THE INTERNATIONAL MARKET OF EDUCATIONAL SERVICES. PROBLEMS AND SEARCHES FOR THE FORMATION OF AN INTERNATIONALIZATION MODEL OF EDUCATION}

This article is devoted to actual subject - the study of transformational processes in Russian higher education. The author examines the phenomenon of massification of higher education and its impact on education system. Phenomenon globalization and internationalization of higher education is analyzed in article. The article considers the issues of export of educational services in the context of the university internationalization. This phenomenon is the main factor in improving education. The author pays attention to the role of a regional university in the implementation of Russia's strategy to strengthen its position in the international education market. This article might be interesting for experts dealing with the development of the export potential of the Russian higher education system.

Key words: export of education, globalization, internationalization, transformation of education.

Бесспорно, проблема и поиски формирования модели интернационализации услуг высшего образования в современных условиях формируемого постбиполярного мира является актуальной и требует своего пристального внимания. Сегодня как в научно-исследовательской литературе, так и политической практике вопросы международной деятельности российских вузов остаются важнейшими не только для российского, но и мирового профессионального сообщества. Так, в Декларации первой международной конференции «Высшее образование в XXI веке: подходы и практические меры» (Париж 1998, ЮНЕСКО) [4] отмечалось, что повышение качества высшего образования в новом столетии является важнейшей задачей мирового сообщества. Прежде всего, модель высшего образования 
должна иметь международное измерение. Наряду с учетом национальных культурных ценностей и условий развития государств это обстоятельство предполагает широкий спектр совершенствования профессиональной деятельности: обмен знаниями, создание интерактивных сетей, повышения мобильности преподавателей и учащихся, активности международных научно-исследовательских проектов и т.д. Надо понимать, что современные вызовы порождают новые тенденции в высшем образовании. При этом три из них - это интернационализация, увеличение масштабов высшего образования, и диверсификация являются ключевыми. Но необходимо признать еще одни неоспоримый факт: сегодня данная тенденция стремительно набирает силу и приобретает все более реальный характер.

Следует подчеркнуть, что в работах российских авторов, опубликованных в последние годы, освещается широкий спектр вопросов близких к данной предметной области [2. С. 1103-1109; 3. С. 56-75; 5; 7; 10. С. 7-25; 11; 15. С. 349-350].

Однако проблему формирования российской модели образовательных услуг на международном рынке нельзя назвать однозначно исчерпанной. В силу многих объективных обстоятельств изучение обозначенной темы продолжает сохранять высокий уровень актуальности.

Важный этап в дискурс данной проблематики внесло письмо Заместителя Министра образования и науки Российской Федерации А.А. Климова от 28.06.2012 г. № АК-6/12. Согласно ему Российский Союз ректоров провел межвузовское экспертное обсуждение «Примерного перечня критериев общероссийской системы оценки эффективности деятельности высших учебных заведений» [14] добавило к обсуждению новые акценты. Вопросы интернационализации российской высшей школы стали предметом внимания и на страницах научных журналов и дискуссионных площадках. В научном сообществе популярно мнение, что термин глобализация является синонимом интернационализации, или ее прямым следствием. Длительное время определение «интернационализация высшего образования» является предметом многочисленных дискуссий. В контексте данного дискурса, с методологической точки зрения исходя из непреложного факта, что интернационализация - это объективный процесс современных международных отношений, автор дает свое понимание данной дефиниции. Поэтому под интернационализацией высшего образования автор понимает устойчивое взаимодействие и взачмовлияние национальной системы высшего образования, в основе которой лежат цели и принципы, отвечающие потребностям и тенденциям нового столетия. При этом автор учитывает и определение Дж. Найта, которая уточнила, что этот процесс имеет место быть на национальном, отраслевом и институциональном уровне. Именно здесь проходят различные интеграционные процессы международного, межкультурного или глобального измерения [26]. Вводя 
термин «глобализация» в понимание сущностных и процессуальных процессов интернационализации высшего образования, надо понимать еще один факт, что эти две дефиниции, без сомнения, имя общие элементы, в значительной мере отличаются от концептуального содержания. Термин «глобализация» обозначает более сложную и методологически глубокую систему взаимосвязи и является более изученной. Научное сообщество подготовило массивы данных, объясняющих какие процессы неизбежно влияют на локальные сообщества и их возможные реакции. Влиянию процессов глобализации подвержены многие аспекты повседневной жизни [23]. Более того, на основе транснационализации и регионализации, тесное переплетение локальных и глобальных проблем послужило рождению глобальных проблем. Благодаря данному обстоятельству, по мнению автора, произошло формирование единой мировой сетевой системы интернационализации высшего образования, что является ключевым аспектом в рамках исследуемой проблемы. Исследования, проводимые на тему интернационализации образования в свою очередь сосредотачиваются на общих темах, лежащих в основе данной концепции. Из них выделяют: результаты и управление. Многие исследователи сходятся во мнении в том, что процесс интернационализации высшего образования определяется различными формами и моделями. Так, например, в Генеральном Соглашении по Торговле Услугами ВТО описана модель торговли образовательными услугами, которая как любая бизнес-модель, имеет различные этапы, инвестиции в ресурсы, управленческий контроль, риски, доходность [20. Р. 359-381]. Основным результатом интернационализации высшего образования, помимо непосредственного дохода университета, является развитие человеческого капитала, которые способствуют социальному и экономическому развитию региона. Поскольку интернационализация высшего образования должна происходить на всех уровнях университета, то управление процессами интернационализации университета также должно проходить на всех уровнях. Эксперты, занимающиеся вопросами экспорта образовательных услуг, сходятся во мнении, что невозможно качественно развивать экспорт образовательных услуг без изменения и интернационализации внутренней среды университетов. Мария Канту, к примеру, в своих работах выделяет три составляющие интернационализации американских университетов: обучение за рубежом, набор иностранных студентов и интернационализация кафедры [21. Р. 2-12].

Так, в 2009 году проводился исследовательский проект, в котором приняло участие 6391 человек. Согласно данному исследованию, обучение за рубежом влияет на 5 основных аспектов глобальной вовлеченности человека, таких как: гражданская активность, знание производства, благотворительность, социальное предпринимательство и волонтерство. Все эти аспекты повышает конкурентоспособность выпускника на трудовом рынке. 
Набор иностранных студентов - это один из основных инструментов пополнения бюджета университетов вне зависимости от страновой принадлежности. Под интернационализацией кафедры Мария Канту понимает студенческий и преподавательский обмен (академический обмен), исследовательские гранты, развитие профессорско-преподавательского состава кафедры, а также развитие учебных планов. Однако, некоторые исследователи полагают, что если бюджет университета располагает средствами для развития лишь только одного направления интернационализации, то даже при этом необходимо заниматься таким направлением, как развитие интернационализации кафедры. Это - крайне важно для развития университета и его включенности в мировое образовательное и научное пространство. Благодаря интернационализации высшего образования в научный оборот был введен такой термин, как массовизаиия образования. В данном случае его введение обусловлено появлением большого количества мобильных студентов, сокращения бюджетного финансирования университетов и обострения конкурентной борьбы за закрепление своих позиций на мировом рынке образовательных услуг. Все это дало толчок глубинным трансформационным процессам в сфере университетского образования, а также обусловило появление такого нового формата международных экономических отношений, как импорт образовательных услуг [8. С. 3]. К примеру, количество мобильных иностранных студентов в мире с 2 млн по сравнению в 2000 году, выросло до 5,3 миллиона в 2017 году (ЮНЕСКО, 2019). Более половины были зачислены в следующие шесть стран: США, Великобритания, Австралия, Франция, Германия, Россия [25]. В борьбе за иностранных обучающихся многие страны отвечают на вызовы глобализации разными способами. Но весь инструментарий сходится в одном - в повышении качества научной среды, образования и образовательных услуг. В западных университетах изменения начали происходить несколько десятков лет назад. Так, например, согласно Волкову А.Е., для Франции «рейтинговый шок» наступил в 2003 году, тогда как в России только в 2013 году. В России, помимо общепринятой академической революции, проходили процессы глубокой трансформации советской модели образования. Период 1990 гг. по 2000 гг. ознаменовался появлением большого количества частных университетов. Более того, многие институты при проведении аттестации или самостоятельно принимали на себя статус университетов. Именно такие университеты стали доступны для большого количества студентов. С точки зрения Альтбаха Ф., «... чрезвычайная диверсификация студенческого корпуса сопровождается общим снижением качества, причем как качества студентов в плане их академической подготовки, так и качества самих учреждений высшего образования». Сделав упор на массовизацию образования, большинство университетов перестало обращать внимание на необходимость так называемого производства знаний. В данном контексте производство знаний 
следует понимать исходя из категории такой отрасли научных знаний, как экономика. К примеру, Алексеева С.А., определяя термин «экономика знаний», анализирует требования к человеческому капиталу. Экономика, основанная на знаниях, повышает качество выпускников, решает вопросы профессиональной занятости [1. С. 1-4]. При этом глобальная экономика предъявляет выпускникам следующие требования: открытость, наличие коммуникативных навыков и знание иностранного языка, аналитические навыки, гибкость мышления, критическое мышлением, способные работать в команде, терпимость и уважение к другим [24. Р. 205-232; 22. Р. 184-204]. По мнению Щербенка А., директора центра перспективных исследований Тюменского государственного университета, практикующего профессора центра развития образования Сколково, для российской модели обучения, лучший способ ввести человека в проблематику - это прочитать ему обзорный курс. Но автор полагает, что подобная модель не позволяет получить компетенции и навыки, необходимые для успешного построения карьеры. Поэтому перед университетами в целом, и обществом в частности, государство поставило новые задачи, которые невозможно решать, не изменив, в целом, всю модель поведения [18. С. 17-23]. Высшее образование в России в последние время подвержено влиянию различных активных трансформационных процессов, без проведения которых высшая школа не может выдержать конкурентную борьбу в стремительно меняющемся глобальном мире. Волков А. Е., указывает на то, что только многопрофильные университеты способны решать разносторонние задачи каждого субъекта Российской Федерации [18. С. 17-23]. Несмотря на возрастающий интерес России к укреплению своих позиций на мировом рынке образовательных услуг, отмечают эксперты, результат по привлечению иностранных обучающихся в российские вузы остается недостаточно высоким и составляет около 5\% от общего количества иностранных студентов. В 2012 году правительство России поставило перед системой образования амбициозные задачи: значительно повысить уровень и развитие своего экспортного потенциала. Для этого университеты должны играть лидирующую роль в развитии технологий и инноваций. Так, для повышения конкурентоспособности ведущих российских университетов в 2012 году был запущен проект «5-100». При этом ключевым направлением правительством России было определено повышение количества иностранных обучающихся в российской высшей школе. Согласно приоритетному проекту от 2017 года «Развитие экспортного потенциала российской системы образования», количество иностранных обучающихся должно возрасти к 2025 году с 200 тыс. до 710 тыс. Объем денежных средств, полученных от иностранных обучающихся, должен быть увеличен до 373147 млн. руб. [12]. Сегодня правительство Российской Федерации продолжает оказывать активную финансовую поддержку университетам. Так, 30 декабря 2020 года утверждена программа стратегического 
лидерства (программа «Приоритет-2030»). Прежде всего данная программа направлена на реализацию прорывных научных исследований и разработок в высшей школе. В приоритете развитие отраслей экономики и социальной сферы, а также внедрение в эти сферы высоких технологий. Исходя из комплекса принятых мер развитие экспортного потенциала российской высшей школы остается одним из приоритетов развития на ближайшие десятилетия. За последние 18 лет в системе высшего образования проходили очень динамичные изменения. По мнению Волкова А.Е., самые активные трансформационные процессы проходят сейчас именно в России. За последние пять лет можно наблюдать улучшение позиций российских университетов в международных рейтингах. Так, согласно Times Higher Education 2020, лучшим российским вузом определен Московский государственный университет им. М.В. Ломоносова, занявший 189 позицию мирового уровня [13] (Табл. 1).

Это обусловлено государственной поддержкой университетов, направленной на укрепление позиций российских университетов. Необходимо подчеркнуть, что представительство российских университетов в подобных рейтингах ограничена небольшим количеством ведущих учебных заведений. Региональные вузы практически не вошли в данный рейтинг. Важно отметить, что репутация университета на глобальном уровне является главным фактором конкурентного преимущества на международном образовательном рынке. Несмотря на продолжающиеся дискуссии вокруг манипулирования данными в международных рейтингах и их ангажированности, попадая в них, университет становится привлекательным не только для абитуриентов, но и для регионального правительства, работодателей. У высшего учебного заведения появляется возможность привлекать инвестиции [6]. На уровне правительства, научного и бизнес сообщества ведется активная дискуссия о роли регионального университета в развитии субъекта Федерации. Вузам отводится приоритетная роль в формировании и реализации инновационной стратегии в России и ее регионах. Для повышения качества жизни населения именно региональные университеты должны заниматься воспроизводством кадрового и научного потенциала региона [16. С. 56-57]. Говоря о региональном факторе и интересе к интеллектуальной деятельности университета, необходимо отметить парадокс, который подчеркивает Мельник Д. Для того, чтобы решать задачи региона, университету в любом случае необходимо быть включенным в мировую интеллектуальную сеть, в противном случае вузу неоткуда будет брать новые теории и практики [17. С. 9-15]. Региональные университеты должны быть интересными не только для локального сообщества, а в первую очередь, для глобального, иметь уникальные компетенции и экспертизу. Деятельность региональных университетов, связанная с экспортом образовательных услуг, где в первую очередь он должен продвигать внешнеполитиче- 
Таблица 1

\section{Позиции российских университетов в международных рейтингах}

\begin{tabular}{|c|c|c|}
\hline № & Ведущие учебные заведения & № в мире \\
\hline 1. & $\begin{array}{l}\text { Московский государственный университет } \\
\text { имени М.В. Ломоносова }\end{array}$ & 189 \\
\hline 2. & $\begin{array}{l}\text { Московский физико-технический институт } \\
\text { (государственный университет) }\end{array}$ & $201-250$ \\
\hline 3. & $\begin{array}{l}\text { Национальный исследовательский университет } \\
\text { «Высшая школа экономики» }\end{array}$ & $251-250$ \\
\hline $4-5$. & Университет ИТМО & $401-500$ \\
\hline $4-5$. & $\begin{array}{l}\text { Национальный исследовательский ядерный } \\
\text { университет «МИФИ» }\end{array}$ & $401-500$ \\
\hline $6-8$. & $\begin{array}{l}\text { Национальный исследовательский Томский } \\
\text { государственный университет }\end{array}$ & $501-600$ \\
\hline $6-8$ & $\begin{array}{l}\text { Санкт-Петербургский государственный } \\
\text { политехнический университет Петра Великого }\end{array}$ & $501-600$ \\
\hline $6-8$ & $\begin{array}{l}\text { Новосибирский национальный исследовательский } \\
\text { государственный университет }\end{array}$ & $501-600$ \\
\hline $9-12$. & Казанский (Приволжский) федеральный университет & $601-800$ \\
\hline $9-12$. & $\begin{array}{l}\text { Национальный исследовательский технологический } \\
\text { университет «МИСиС» }\end{array}$ & $601-800$ \\
\hline $9-12$. & Санкт-Петербургский государственный университет & $601-800$ \\
\hline $9-12$. & $\begin{array}{l}\text { Национальный исследовательский Томский } \\
\text { политехнический университет }\end{array}$ & $601-800$ \\
\hline
\end{tabular}

скую и внешнеэкономическую деятельность конкретного региона. Через подобное развитие международного сотрудничества будут выстраиваться и экономические связи. Необходимо учитывать, что внутренняя миграция и убыль населения с большинства российских регионов в крупные экономические центры с диверсифицированными рынками образования и труда сильно усугубляют ситуацию в региональных университетах. В регионе остаются не самые подготовленные абитуриенты. Это, в свою очередь, запускает процессы отставания от мирового образовательного рынка. Щербенок А., в прочитанной в «Школе ректоров 18» Сколкова в авторской лекции указывает на то, что «отток качественных абитуриентов в более престижные университеты представляет собой проблемы. Этот отток не дает возможность региональному университету интенсивно развиваться и, более того, запускает процессы прогрессирующей деградации». Существующие 
антагонизмы часто тормозят развитие университетов. Следовательно, перед региональными университетами стоят колоссальные задачи. Необходимо четко понимать, что собой представляет региональный университет, какую нишу он занимает, как он действует, каким себя видит в будущем, какой уникальный продукт он производит. Это позволит сократить разрыв между внутренним и внешним позиционированием.

Таким образом, подводя итоги исследованию образовательных услуг как ключевому фактору повышения качества образования, автор сделал следующее заключение. Интернационализация образования, как ответ на мировую глобализацию, является важнейшим инструментом внешнеполитической деятельности России. Многие эксперты отмечают, что конкурентоспособность экономики той или иной страны напрямую зависит от увеличения роста экспорта образовательных услуг [19]. Интернационализация университета сегодня рассматривается не только как средство повышения качества образования, научных исследований, но и как эффективного внешнеполитического влияния страны. Развитие науки и образования являются основными целями для достижения национального и регионального развития. Будучи интересными глобально, региональные университеты смогут решать задачи, которые ставит перед ними региональное и федеральное правительство.

\section{БИБЛИОГРАФИЧЕСКИЙ СПИСОК:}

1. Алексеева C.A. Экономика знаний и человеческий капитал // Обучение иностранным языкам: от профессионализации к профессионализму: материалы научно-методического межвузовского семинара 11 ноября 2009 г., Москва. Москва: МГИМО-Университет, 2010.

2. Береснев Д.Н., Медведев Н.П., Слизовский Д.Е. Рецензия на статью Датукишвили Е.3., Мусиной Н.К., Преждаровой В.Г., Симоновой С.В. «Образование: как государство воздействует на эту хрупкую и пластичную систему» // Вопросы политологии. 2018. Т. 8. № 11 (39).

3. Береснев Д.Н., Береснев Р.А., Слизовский Д.Е. Российско-германское научное, техническое и образовательное сотрудничество: состояние и перспективы // Евразийский Союз: вопросы международных отношений. 2019. T. 8. № 1 (27).

4. Всемирная декларация о высшем образовании для XXI века: подходы и практические меры (принята в г. Париже 05.10.1998-09.10.1998 на Всемирной конференции ЮНЕСКО Высшее образование в XXI веке: подходы и практические меры) // https://www.lawmix.ru/abrolaw/9374.

5. Жалнин B.A. Теоретический инструментарий анализа государственной политики в сфере образования и науки как конфликт групповых и личностных интересов // Евразийский Союз: вопросы международных отношений. 2020. Т. 9. № 1 (31). 
6. Зачем нужны рейтинги университетов // Ведомости. 2017 // https:// www.vedomosti.ru/opinion/articles/2017/07/17/723970-reitingi-universitetov.

7. Комлева В.В. Развитие экспорта российского высшего образования: основные противоречия // Вопросы политологии. 2020. Т. 10. № 6 (58).

8. Косевич A.B. Экспорт образовательных услуг сферы высшего образования: мировой опыт и российская практика: дис. ... канд. эк. наук: 08.00.14. M., 2006.

9. Махотаева M.Ю. Экспорт образовательных услуг vs интернационализация университета: монография / М.Ю. Махотаева, О.А. Бакуменко, Г.В. Варламов. СПб.: Изд-во Санкт-Петербургского университета технологий управления и экономики, 2019. DOI: 10.1177/1028315317697540.

10. Медведев Н.П., Слизовский Д.Е., Ахмадиен К.С., Кузнеиова Е., Репьева Я. Российская Федерация ищет способ обеспечить развитие экспортного потенциала своей системы образования // Вопросы политологии. 2017. № 4 (28).

11. Медведев Н.П., Слизовский Д.Е., Жалнин В.А. Возможна ли реформа университетского образования? Послесловие к статье Комлевой В.В. «Развитие экспорта российского высшего образования: основные противоречия» // Вопросы политологии. 2020. Т. 10. № 6 (58).

12. Паспорт приоритетного проекта «Развитие экспортного потенциала российской системы образования // Правительство России. 2017 // http:// government.ru/projects/selection/653/28013.

13. Рейтинг вузов Times Higher Education. 2020 // https://www.provuz.ru/ rating/times-higher-education-2020/.

14. Сводные предложения Российского Союза ректоров по формированию перечня критериев оценки эффективности деятельности высших учебных заведений // https://rsr-online.ru/doc/norm/545.pdf.

15. Слизовский Д.Е., Шуленина Н.В. Государственная политика РФ в отношении образования: противоречия элементов новизны и отмирающих форм // В сборнике: Время больших перемен: политика и политики. Материалы Всероссийской научной конференции РАПН. Российский университет дружбы народов; Под редакцией О.В. Гаман-Голутвиной, Л.В. Сморгунова, Л.Н. Тимофеевой. 2017.

16. Университет как двигатель регионального экономического развития: презентационный материал: Н.С. Кучма. РУДН, 2020.

17. Что происходит в мировом высшем образовании: экспертный доклад / Д. Мельник. Т-Университеты: Центр трансформации образования Московской школы управления СКОЛКОВО, 2019.

18. Что происходит в российском высшем образовании: экспертный доклад / А.Е. Волков. Т-Университеты: Центр трансформации образования Московской школы управления СКОЛКОВО, 2019. 
19. Экспорт образования: дайджест мировых тенденций // Аккредитация в образовании // https://akvobr.ru/eksport_obrazovania_daidzhest.html.

20. Alsharari N.M. Internationalization of the Higher Education System: An Interpretive Analysis // International Journal of Educational Management. 2018. Vol. 32. Issue: 3. DOI: 10.1108/IJEM-04-2017-0082.

21. Cantu M.P. Three Effective Strategies of Internationalization in American Universities // Journal of International Education and Leadership. 2013. Vol. 3 (3). ISSN: 2161-7252.

22. Chan W.W., Dimmock C. The Internationalization of universities: Globalist, internationalist and translocalist models // Journal of Research in International Education. 2008. Vol. 7 (2). DOI: 10.1177/1475240908091304.

23. Globalization of Education // Education Encyclopedia - StateUniversity. com//https:/education.stateuniversity.com/pages/2010/Glob alization-Education. html.

24.Hayden M.C., Thompson J., Williams G. Studentperceptions of international education: A comparison by course of study undertaken // Journal of Research in International Education. 2003. Vol. 2 (2). DOI: 10.1177/14752409030022005.

25. International students // Migration data portal. The bigger picture // https:// migrationdataportal.org/themes/international-students.

26. Knight J. Updated Definition of Internationalization // International Higher Education. 2003. Vol. 33. DOI: 10.6017/ihe.2003.33.7391. 